\title{
Eric R. Boot, Human Duties and the Limits to Human Rights Discourse
}

\author{
Dascha Düring
}

Eric R. Boot, Human Duties and the Limits to Human Rights Discourse (Cham: Springer, 2017), $183 p$.

In Human Duties and the Limits to Human Rights Discourse, Eric Boot develops a critical view on what he calls the 'rights infatuation' (p. 3) of contemporary political and juridical discourse and calls for a renewed attention to duty to strengthen human rights. The book makes for an interesting read, and especially the chapters which discuss human duties in international human rights law (ch. 2) and the 'contentious' international individual duties of aid and duties to the community (ch. 4) are an interesting contribution to the academic literature on human rights. Boot's conceptual reconstruction of the 'perspective of duties' (esp. p. 68-71) and the normative commitments that he claims will follow from adopting the latter, however, raise a variety of philosophical concerns. I here raise those that I deem most fundamental.

Boot develops his idea of the perspective of duties in contradistinction to that of the 'perspective of rights' which on his view dominates contemporary legal and political discourse. This perspective of rights, Boot claims, works from the presumption that rights are the most fundamental moral category and that duties exist only to the extent that they stem from rights (p. 3). Indeed, he argues, 'Lacking other normative concepts [than that of rights], the perspective of rights can do nothing but treat everything that does not amount to a violation of rights as permissible and morally acceptable. So long as one does not wrong another, one acts rightly' (p. 69). The perspective of rights is thus, Boot stresses, a morally impoverished one: it reduces moral philosophy to rights talk and is incapable of providing any conceptual tools for judging dimensions of human action and agency that cannot be framed in terms of rights (esp. p. 3, 73, 176). As such, his book attempts to complement the perspective of rights with a perspective of duties.

Taking his inspiration from Kant, Boot suggests that the perspective of duties offers a moral viewpoint that revolves around the question 'What should I do?' rather than 'What are my rights?'. This perspective, he thinks, has the potential not only to enrich the playing field of modern moral philosophy but also to clarify our understanding of human rights - to clarify which kinds of rights are genuine, and which claims are inauthentic appeals to the status of human rights (p. 4). Building further on Kant and contemporary Kantians, Boot emphasizes the importance of recognizing different sorts of duties: duties of justice on the one hand and duties of virtue on the other. The former, Boot says, are duties concern- 
ing which it is clear 'who must do what for whom' (p. 54). These duties are, in other words, determinate, and as such can have corresponding rights which may be enforced. Because the duty to refrain from murder clearly implies that, for example, you must refrain from murdering me, this duty can give me a corresponding right not to be murdered which may be enforced. Duties of virtue, however, work differently. Although these likewise formulate answers to the question 'What should I do?', these answers are conditional upon the judgment of particular persons in particular circumstances. For example, as Boot says, 'We may promote the happiness of those in need by aiding them materially (that is, by donating money), but how much we ought to give depends on our means, on the presence or absence of social security, on our knowledge of the precise needs of specific others, and on a myriad of other contingent factors. But we may also help them politically, by lobbying for expansion of the social safety net, for instance' (p. 45). Duties of virtue are, in other words, indeterminate, and as such these have no corresponding and enforceable rights - duties of virtue cannot be claimed or owed but can only be granted by way of 'free self-constraint' (p. 55). But this latter feature, Boot argues, does not make duties of virtue of lesser moral importance to duties of justice. Indeed, contrary to what is supposedly popular moral belief, Boot holds that duties of virtue are just as morally binding as duties of justice. The difference is only that, because of their indeterminate nature, duties of virtue cannot have corresponding and enforceable rights.

As said, Boot thinks that recognizing this will not merely enrich the playing field of modern moral philosophy. It will also clarify our understanding of human rights. Human rights, namely, can only be those claims of which it is clear who must do what for whom. When this is not so clear, when there is a degree of indeterminacy in how morality asks one person to behave vis-à-vis another, then we supposedly have no reason to speak of human rights at all - as Boot says is the case with individual duties of aid to the distant poor and duties to the community. Indeed, he says, we may not speak of human rights in such cases because this would amount to unjustifiable coercion of the autonomous individual. Claims to an adequate standard of living, such as claims to breathable air or drinkable water, are not human rights at all. They are 'inauthentic' claims to the status of rights (p. 178), which can ground duties of virtue and not duties of justice on behalf of others. And recognizing this, supposedly, is 'of great benefit to our rights' as it prevents 'unclaimable rights from arising' (p. 177).

Considering that this latter point is ultimately what Boot aims to drive home, there appear some gaps in his argumentative structure. Boot introduces his project as if he is worried about the moral impoverishment of contemporary political and legal discourse, but simultaneously - and other than various communitarian academics as well as political leaders such as the late mr. Lee Kuan Yew - wants to retain an unambiguous endorsement of human rights. As such, and also because it remains obscure whom exactly Boot's criticism is directed to (he tends to speak about 'liberal political theory' or 'contemporary human rights discourse' as if these do not carry the most opposing views), it seems as if he intends to build a 
case for an open and inclusive political and legal discourse that balances an unabated endorsement of the project of human rights with a keen respect for the moral importance of human duties. This is not, however, how the argument plays out. By making a strict notion of determinacy the criterion of a right that may justifiably be enforced, Boot covertly tears at the normative foundation of the human rights project so that it becomes questionable whether he can uphold his purported unambiguous and unabated support of the latter.

On Boot's view, after all, only those claims of which it is evident who is the corresponding duty-bearer as well as what the latter owes to the claimant can make a legitimate appeal to the status of human rights. But there are good reasons to ask whether the biggest threats to the dignity of persons fall into this category in the first place. Even when we consider some of the most fundamental and relatively 'straightforward' violations of human dignity like impositions of severe physical harm in the form of, for example, mutilation or torture, it is questionable to what extent it is clear and determinate who owes what to whom. Yes, in these cases the rights-violators obviously include the ones who yield the blade - but not only the latter! It also includes those who gave the order, those who built the formal institutions that make giving such orders possible, perhaps even those who spearheaded the informal institutions and ideologies that portray mutilation or torture as permissible or required. To live up to their purpose of protecting human beings from far-reaching harm, human rights need the ability to criticize and challenge especially also those latter institutional structures: the institutions that enable or even encourage individuals to violate the dignity of their fellow human beings. But the interposition of such institutional structures makes that even the most atrocious violations of human dignity are rarely violations that ground claims of which it is evident who precisely owes what to whom. When we consider the millions of women and girls who suffer (or die) from the effects of genital mutilation, it seems clear that their (potential) claims to have their dignity respected are not merely directed towards the 'doctors' who cut them up. To make any sense whatsoever, these must be interpreted also as directed towards family and clan representatives, towards religious ministers, towards governments - judging who owes what to whom is, even when the most atrocious violations of human dignity are concerned, often a messy business. But since Boot made determinacy the criterion of a human right, claims in such messy contexts can supposedly not appeal to the status of rights at all. And that, at least without further ado, seems an aggravated assault against human rights as a normative framework and project.

Maybe Boot would answer that I am now downplaying the significance of human duties. And maybe I am. Maybe it is reasonable to expect that more 'duties talk' will diminish practices like female genital mutilation. But insofar as Rousseau had a point when he said that justice requires us to take men as they are and laws as they might be, there may also be good reasons for holding that enforceability matters. And if that is so, then we are still in dire need of human rights - and not merely human duties - especially in those cases where violations of dignity are deeply, and possibly messily, embedded in institutional structures. 